\title{
Global Effects of COVID-19, government restrictions and implications for sex workers: A focus on Africa
}

Rosie Campbell, Teela Sanders, Rahma Hassan, Susan Gichuna, Mercy Mutonyi, Peninah Mwangi

\begin{abstract}
There has been an unusually high media reporting of the impact on sex workers across the globe in relation to Covid -19 and related government lockdown, movement restrictions and reduced employment. This paper utilises a media analysis which examined $\mathrm{N}=541$ media articles identified for the period 1st March to 31st May. $\mathrm{N}=103$ of these focused on different countries in Africa and $\mathrm{n}=43$ articles had a Kenyan focus. The media analysis is important as it is a lens through which sex workers are constructed, discourses are reinforced and knowledge is transferred throughout the globe. In this paper we reflect on: 1) The global effects on sex workers to show generic trends around economic impacts and health care across the global north and south; 2) core themes which affected sex workers daily lives across the African continent such as changes in mobility in cities and across borders, reduced movements, police interactions and violence, homelessness; 3 ) outline some of the global and localised responses from sex worker rights organisation, support projects and NGO's, in the absence of government safety nets. These media reports have illuminated the crisis experienced by sex workers during the period of initial first wave occurrences of Covid in countries globally and governmental measures to suppress the virus. These reductions in income, access to health care and medicines and challenges for housing will persist for some time with devastating effects on an already vulnerable and marginalised community.
\end{abstract}

\section{Introduction: Contextual Factors affecting sex workers}

Prior to the Covid-19 crisis sex workers were a population who were already experiencing significant hardships across the globe, in relation to the criminalisation of their working environments causing health inequalities (Platt et al., 2018), the burden of violence (Deering et al., 2014 and long term trends in relation to HIV (Birdthistle et al., 2019). Our focus in this paper is on the experiences of sex workers in Africa, and in particular in Kenya, as a result of knowledge gained over the last few years through various research projects working in partnership with the Bar Hostesses Empowerment and Support project. With health systems fragile in many African countries, and already under pressure responding to the HIV pandemic, a key concern expressed by global health organisations has been the impact of coronavirus on HIV, testing, prevention and treatment. UNAIDS issued a press statement on $11^{\text {th }}$ May 2020 following a modelling exercise they carried out, suggesting serious disruption to health services and supplies caused by the Covid-19 pandemic over a number of time periods. ${ }^{1}$ They highlighted a number of specific consequences for HIV testing, prevention and treatment of people living with HIV and pointed to potential adverse consequences for the African continent. ). Research has documented how women are disproportionately affected by pandemics (Howard 2020; Wenham; Smith; Morgan 2020) and whilst people of all genders sex work, women form the majority of sex worker globally. A consortium of seven international NGO's including Oxfam, Action Aid, Help the Aged International produced a report published by the Danish Refugee Council (2020) in early May. This report documented how the East Africa and Great Lakes area was already 'food stressed' before the Covid-19 pandemic with the region hosting almost a quarter of the world's acutely food insecure people, and $20 \%$ of the global total of food insecure people. Covid- 19 was to further exacerbate this alongside the largest locust swarms for decades. A large 
proportion of the population of the region have 'fragile livelihoods', with $80 \%$ of non-agricultural work needed to be performed outside the home, lockdowns would have severe affects.

Kimani et al., (2020:1) noted that middle and low income countries had experienced a relatively low burden of Covid-19 infection, but the responses to the crisis 'have had particularly dire consequences for impoverished populations, many of whom rely on regular income in the informal economic sector to survive'. It is within the context of concerns about the capacity of a health care system already dealing with the HIV crisis, pre-existing food stress and insecurity, large numbers of people in the informal economy and large vulnerable populations (such as people living with HIV, homeless people, refugees, people living within informal or marginalised settlements), that the Covid-19 crisis in Africa and Kenya must be understood.

\section{Aims and Methods}

For this study the objective was to provide a summary global overview of the impact of Covid-19 pandemic on sex work (with a focus on the continent of Africa) to set the context for our empirical study carried out in Nairobi the capital of, and largest city, in Kenya (East Africa). ${ }^{2}$ This empirical project with partners Bar Hostess Empowerment and Support Project (BHESP) supporting sex workers across the city. It has been important to review the global media at the time of Covid across the world, as the media is an important lens through which we come to understand the world, and in particular how sex work is represented, constructed and addressed by governments.

This review is informed by;

- Global online media reports (restricted to English language media).

- Briefings, news reports, statements and blogs from established sex worker rights organisations and networks.

- Published academic articles on sex work and Covid-19.

We are very much aware that media representations of sex work often do not represent the varied and complex lived realities and experiences of sex workers, it is not always the place to look to for the 'facts'. We are also aware that the journalistic standards applied by those reporting on sex work are varied, as are their ethical standards of practice when investigating sex work news matters. The media is one socio-cultural area where narratives around sex work are constructed hence it's important to engage with and deconstruct the narrative. Media is also a space where sex worker voices can break through and be heard: advocacy groups globally are often effective communicators and engage with the media as part of advocacy and campaigns. We raise these points to stress that we are very aware of the limits to media reportage on sex work.

Between April $1^{\text {st }}$ and $1^{\text {st }}$ June the researcher received daily google media alerts for the following search terms such as 'Sex work and corona virus'; 'Sex work and Covid-19'; 'Prostitution and corona virus'; Prostitution Kenya Covid-19. The alerts were examined for articles between $1^{\text {st }}$ March and $31^{\text {st }}$ May 2020. This time frame was chosen because it was the start of the lockdown periods for many countries and in particular in Kenya. The media reports were organised into regional areas used by the Global Network of Sex work Projects. These regions are Africa, Asia and the Pacific, Europe, Latin America, North America and the Caribbean. The only exception outside this timeframe was an article with an African focus with considerable coverage of Kenya which had grown out of advocacy by Kenyan Sex Work Alliance (KESWA) ${ }^{3}$ on International Sex Worker Day on $2^{\text {nd }}$ June, BHESP were involved in that advocacy. Within alerts received as of $1^{\text {st }}$ June a total of $\mathrm{N}=541$ media articles were identified for the period $1^{\text {st }}$ March to 31st May. $N=103$ of these focused on Africa and $\mathrm{n}=43$ articles had a Kenyan focus or substantive reference. The African articles were subject to content analysis using NVIVO. Here we entered all of the articles into the software and used the process of creating nodes to find out the core themes that were present. We used a thematic 
analysis approach to find the core themes and subthemes on which these findings report. The international articles were read and key themes recorded. $\mathrm{N}=144$ were Asia and the Pacific, $\mathrm{N}=108$ Europe, $\mathrm{N}=20$ Latin America, $\mathrm{N}=142$ North America and the Caribbean, with $\mathrm{N}=24$ global features. The methodology for understanding these articles was qualitative content analysis, with view to finding out the most significant impacts experienced by sex workers during this unprecedented times.

\section{A Global Summary}

The global media reportage, academic literature published to date and sex work support and rights organisations narratives about Covid-19 and associated policy responses and how these have impacted sex workers, paint a picture of a perfect storm which has severely disrupted sex workers livelihoods, the businesses they work within, their access to health and wider support services. This in turn has further heightened stigma, criminalisation and violence, eroding their safety. With corona virus passing easily from human to human, with in person sex work requiring close contact, social distancing is difficult to implement and hence sex workers (and their customers) fears about transmission was one of the factors leading to a shrinkage in customer numbers. Further reduced by the introduction of government Covid-19 measures in countries across the globe such as lockdown with the closure of none essential businesses, stay at home orders, social distancing requirements, restrictions on movement and curfews leading to the closure of sex work venues and making it very difficult for sex workers to make contact with customers without breaking Covid-19 regulations. This put an end to business as usual for the sex industry globally. This was in a context of national regulatory frameworks across the global where sex work itself or associated activities were already criminalised (decriminalisation is exceptional), sex work was highly stigmatised, human rights abuses and repressive policing was commonplace and violence other targeted crimes against sex workers were common (ICRSE and SWAN, 2020). As UNAIDS (2020:2) noted;

'.....physical distancing measures to prevent the spread of coronavirus may affect the livelihood and safety of sex workers; many will have fewer clients, increasing the risk of homelessness and the need to accept riskier clients. The closing of bars and other hot spots may also cause sex workers to move from a more protected environment to street-based activities, and in settings with strict lockdown measures, they may be at increased risk of arrest.'

With sex workers in the majority of nations already a marginalised, stigmatised and criminalised community, sex workers were already a community of precarious informal workers, they and often their workplaces not formally recognised and often without recourse to safety health and employment protections afforced to those in formal sectors (Platt et al., 2018). Government provisions for Covid emergency aid, crisis economic support for employed and self-employed workers and for businesses in many countries excluded sex workers and /or sex work businesses. Without formal employment status sex workers, could not access crisis government pay schemes. Even in countries where some sex workers were accorded formal status they faced problems regarding exclusion from and access to crisis schemes and welfare provisions (PIC and SexswerkExpertise 2020) Account after account of sex workers experiences in the global South illustrated how sex workers simply did not have the documentation or prior registrations required to access government financial or food aid, including migrants who were excluded from such schemes. In many countries for example UK and Ireland sex workers are effectively self-employed freelancers but may not be registered as self-employed, do not have a tax record or a social security number which are required to access schemes for the self-employed. This lack of a safety net for sex workers in most countries on the African continent heightened hardship and left sex workers under acute 
economic pressure with little choice but to find ways of continuing to sex work to get a basic income for themselves and their dependents, whilst facing risk of infection, stigmatisation and criminalisation for breaching Covid regulations. This exclusion of sex workers from crisis financial provisions and the need for governments to do more, is something sex worker rights organisations and some global human rights NGO's have highlighted.

\section{Global Network Sex Work Project: a global statement}

The Global Network of Sex Work (NSWP) projects is an important source of knowledge about the impact of Covid-19 crisis on sex workers internationally. For over two decades NSWP has worked in adverse circumstances to build a global network committed to upholding the voice of sex workers globally and connect regional networks advocating for the rights of female, male, and transgender sex workers. It connects regional networks across Africa, Asia and the Pacific, Europe, Latin America and North America and the Caribbean. NSWP, on $12^{\text {th }}$ May 2020, published a joint statement with UNAIDS entitled 'Sex workers must not be left behind in the response to COVID-19' 4 amid concerns that the pandemic would further expose inequalities, precarious situations and the exclusion of certain populations from social protections globally. They reported that:

'As a result of the COVID-19 pandemic, sex workers all over the world are experiencing hardship, a total loss of income and increased discrimination and harassment. The criminalization of various aspects of sex work in the majority of countries serves to magnify the already precarious situation of sex workers in the informal economy. As sex workers and their clients self-isolate, sex workers are left unprotected, increasingly vulnerable and unable to provide for themselves and their families' (Global Network of Sex work Projects, 2020).

NSWP on $8^{\text {th }}$ April launched their online Covid-19 impact survey and will be using the findings to document and report to international policy makers about human rights violations putting pressure on them to ensure the needs of sex workers are not ignored in the pandemic. NSWP have produced a number of national case studies based on the survey carried out by Soppeku, a sex worker rights organisation in Senegal ${ }^{5}$. Key results from the situation in Senegal, which were evidenced across Africa are summarised below: ${ }^{6}$

- The imposition of an 8pm to 6am curfew meant there were very few clients.

- Declaration of a state of emergency strict restrictions on travel - for sex workers this meant those who travel to other regions to work in brothels etc were being subject to police raids and racketeering (extortion or other crimes committed through coercion).

- Street sex workers subject to targeted police actions, yet government were putting in place no supports to provide alternative income, so are having to street work to get income for basic and risk police action.

- Reduced access for sex workers to HIV treatments, STI screening and treatment, and basic food and hygiene supplies.

- There is a government system for the distribution of food and personal hygiene supplies donated but these are minimal and not meeting needs. Soppeku are distributing food and hygiene kits in three regions of the country (supported by the Equality Fund). 


\section{Core themes from media analysis}

The salient themes in the African media reflected some of the concerns already flagged by the NSWP. These are listed in order of prominence in media reporting:

- Closure of sex industry venues/areas and reduction of sex work customers and business due to fears about virus transmission and Covid-19 government policies and regulation.

- How sex workers were having to adapt working practices to reduce transmission and avoid risk of action by the authorities under Covid regulations/laws with no option but to earn income through sex work to meet basic needs.

- Loss of income, livelihood and extreme hardship for sex workers.

- Reduced access to health and social support provisions particularly concerns about access to HIV testing and treatment.

- Exclusion of sex workers from government aid, crisis schemes and other protections.

- Criminalisation of sex workers, repressive policing and sex workers breaching regulations.

- Increased violence against sex workers from a range of perpetrators.

- Sex worker self-organising and advocacy including sex worker mutual aid, hardship funds.

- Communities/NGO's/charities/government officials helping sex workers with crisis aid efforts.

- Lorry drivers a concern for the transmission of corona virus and customers of sex workers.

\section{Closure of sex industry venues and reduction of sex work customers}

Referenced in the majority of reports were the dramatically changed circumstances for sex workers with a matrix of factors making it very difficult for sex workers to contact customers and sell services. These factors included; anxiety amongst both sex workers and customers about catching/transmitting the virus, night time curfews, stay at home regulations, restrictions on movement/association, social distancing and a closure of none essential businesses including the bars and hotels where sex workers usually meet their clients. A UNAIDS news feature highlighted the unexpected and severe disruption it had caused for sex workers in Kenya:

Now working full time for the Kenya Sex Workers Alliance (KESWA), she says that the COVID19 lockdown threw everyone into disarray. "At the outbreak, no one was prepared for the coronavirus," she said. "It's not like the rains that we know and can prepare for." The government's lockdown measures to limit the spread of the virus-a dusk-to-dawn curfew and shutting of bars and nightclubs-have left sex workers in Kenya to either work during the day and be very visible or to break the curfew at night. ${ }^{7}$

A feature on Namibian sex workers highlighted the adverse impact of closure of work places and client reductions:

Thirty-year-old Anna Shikongo (not her real name), a sex worker based at the northern border town is among those hard hit by the Covid-19 pandemic which resulted in a decline in economic activities. She and many others are experiencing economic hardships and seeking alternatives for survival. "We can no longer provide our services because most of the accommodation establishments and alcohol outlets are closed and truck drivers, who are the majority of our clientele, have become scarce these days". ${ }^{8}$

South African sex workers described how Covid-19 had reduced customer numbers; 
Some of them recently shared their harrowing tales with Weekend Witness and related how Covid-19 had crippled their industry as they now sometimes go for a whole day without getting a single client. ${ }^{9}$

On April $24^{\text {th }}$ an article entitled 'No clients: Nairobi hookers hit hard by COVID-19 curfew' ${ }^{10}$, whilst utilising some stigmatising language, did focus on the severe effect of Covid-19 and Covid regulations (including the curfew) on the sex industry. The journalists spoke with women working outside venues on the Durhuma Road.

'Nairobi's Duruma Road mirrors a typical street of any of the world's most potent sin cities. Packed outside doors of brothels are tens of prostitutes, braving the afternoon sun and bearing the scrutiny from tens of judging eyes. They are going through a terrible patch, what with business at an unprecedented low and clients unbelievably few. The coronavirus pandemic has caught up with the hustle and bustle of downturn Nairobi, sucking the life out of a once lively area of East Africa's chief business hub... Used to operating in the evenings, it is a change from the norm for the women to be parading for customers in broad daylight all day long to eyes that admire but take not. They, like every other Kenyan, have a curfew to beat, and the time that usually marks beginning of business now signifies end of business. These are odd times, and they can feel it. ${ }^{11}$

The organisation of the sex industry with reliance on the movement of people meant severe consequences;

"Sex workers are mostly affected because they are dependent on the movement of people. Under lockdown there are no people; nobody is allowed to go anywhere, so in turn they have lost an income," Pule said. ${ }^{12}$

Coverage of Ghanaian sex workers in late March entitled 'Coronavirus destroying our business' described the impact at a stage of partial lockdown in a number of cities:

Some commercial sex workers say their business has been hard hit following the outbreak of the Coronavirus (COVID-19) in Ghana. The ladies of the night have lamented the low patronage of their services saying their regular customers from whom they used to make lots of money no more patronize them for fear of contracting the deadly disease. Speaking to Kasapa FM's Bonohene Baffuor Awuah on condition of anonymity, a commercial sex worker stated that the turn of events is making life difficult for them as they are no more making money. She said although they've made sanitizers and wipes available for their customers to clean themselves after sex, they still don't patronize their services. ${ }^{13}$

Sex workers in Nambia during the early weeks of the crisis were experiencing a slowdown of business:

In the wake of the global Covid-19 pandemic, sex workers at the northern border town of Oshikango - who depend mostly on patrons making their way through the border, are struggling to survive. Many have been confined to their lodgings, leaving them wondering where their next meal will come from. Sex workers have also been struggling to cope with mental health issues and physical well-being. Their usual clientele - mostly cross-border traders and long-distance haulage truck drivers in transit to other destinations - have been few and far in between.

For sex workers across the world there has been a shockwave in relation to how their financial income from sex work has disappeared, entirely for many in the short term, but very intermittently for most in the longer term future. In countries where there are criminal laws around arranging and organising prostitution, women in these situations have been hit the hardest as their places of work 
in the form of bars and clubs were closed down for many weeks, and even where opening has taken place they are under high levels of scrutiny.

\section{Adapting working practices}

Many African articles touched on the reality that sex workers had no other option but to try and continue to sell sexual services, this was the case in Nigeria;

Many of the sex workers, who said they had no other means of survival, told our correspondent that they have had to adapt to the reality on ground to put food on their tables. $^{14}$

A feature on the loss of business for sex workers in Nairobi touched on how sex workers have had to make adaptions not only to when and where they work (to try and avoid police) but also to their in person sexual service inter-personal interactions with customers, putting in place harm reduction measures to reduce transmission quoting a sex worker in the city:

They have taken to odd screening of clients and sanitising. Joan from Kasarani says her typical transactions with clients start with discussing how the client feels; if they're experiencing any symptoms. When they get down to the 'real business', Joan says, she doesn't allow clients to kiss her, something she always entertained before. "I ensure we both sanitise our hands before and after sex. This is what the Ministry of Health has directed and it is always fair we do so for our own safety". ${ }^{15}$

Sex workers who work both Tanzanian and Kenyan border truck route areas describe their harm reduction measures:

Heri says she and other sex workers have adopted new practices like not facing clients while having sex and sanitising the parts of their bodies their clients touch, but that they know they were putting themselves at high risk. "We know it's not perfect," she says. "But this job we do, we do to make enough so our kids don't suffer." ${ }^{16}$

South African sex workers described harm reduction measures they were putting in place, reduced income and increasing working hours. ${ }^{17}$ Another article also described how South African sex workers under high pressure to earn income were having to take measures to try and avoid the police:

The women say they hide and then reappear as soon as the police are out of sight, according to a GroundUp report. They still get clients despite the national lockdown. They say their economic survival is a greater worry to them than contracting Covid-19...Asanda also works from the Marikana spot. She said all she had left at home was some mealie meal. "Hunger is killing us ... My regular clients are not coming and police have arrested some ladies," she said. In five days of the lockdown, she only managed to make R60. "I am so broke and desperate right now. There is no way I will stay indoors. Police will have to kill me first if they want me indoors," she said. ${ }^{18}$

A feature on sex work in Nigeria described how workers were devising new 'tactics' to keep their business going after police actions against brothels and sex worker arrested. This included:

They now took the service to the home of willing clients for an agreed fee rather than wait for such customers to come to the brothels, which has become difficult in recent days due to the crackdown by government officials. Sahara Reporters also discovered that more than a few of the commercial sex workers have signed up to some social networking platforms like InMessage to track down willing clients close to their areas of residence..."Now, we talk 
to our clients on phone and we can easily go and sleep over in their houses but this is for those who are yet to marry or are still single among our clients." 19

A short and novel feature highlighted how sex workers have adapted their ways of working to avoid arrest under Covid regulations, featured sex workers in Chipata Gambia adopting the guise of road side breadsellers:

As the impact of coronavirus fight continues to ravage their business, sex workers in Chipata have devised new means of getting clients by pretending to be selling bread at night. This led to a war of words on Wednesday night between genuine bread traders and the sex workers. Regular bread sellers said they did not want prostitutes around their business place. But the sex workers have vowed not to leave the strategic place where to earn some money amid COVID-19. ${ }^{20}$

The desperate need to earn money, to feed themselves and family members has motivated sex workers to be innovative in how they seek out clients, how and when they provide services and how to avoid law enforcement agencies and corrupt encounters.

\section{Hardship, destitution and homelessness}

As has been visible in the previous section all these factors were creating acute financial hardship for sex workers, who were already living precariously, often getting buy day to day, hand to mouth earning enough to put food on the table, pay the rent and other essentials for themselves and for many their families. One Kenyan report spoke with sex workers in Murang'a;

'The women told KNA that their families have been going hungry since the government imposed the curfew measures because of Coronavirus as they could not do their night business and besides, their customers were also indoors'

Another described how;

'Rents have not reduced, and this means that we have to come to town each day to work in order to make money to pay the landlords, "says the woman. ${ }^{21}$

A feature about a land lord using intimidating measures in the Nyalenda slums, against tenants in arrears included a reference to sex workers:

"I woke up to find a fundi on my roof. He said he was under instruction to remove part of the roofing over non-payment arrears," Achieng said. She is in arrears of Sh2,400. She said her earlier efforts to plead for an extension proved futile as the landlady demanded she vacates immediately. "I pleaded with her that I have children and I am not in a position to vacate but she would hear none of it," she said. Achieng says the strict government directives on curfew hours forced her into unemployment. "I work with an organisation that looks into the welfare of sex workers. With the curfew orders in place, we are forced to stay home and lack allowances that come with it," she said.

If we have read this accurately the Covid measures were also impacting on those who work with sex work outreach and support and receive remittance to support sex workers.

On $8^{\text {th }}$ and $9^{\text {th }}$ May BHSEP working with sex work communities on the ground in Korogocho, Kariobangi district, a low-income residential area in North Eastern Nairobi, were able to report on 
the destruction of homes and business by the Nairobi City Water and Sewage Company. Buildings were bull dozed making 5000 people homeless. Many of these people made homeless were sex workers, adding destitution to the list of hardships.

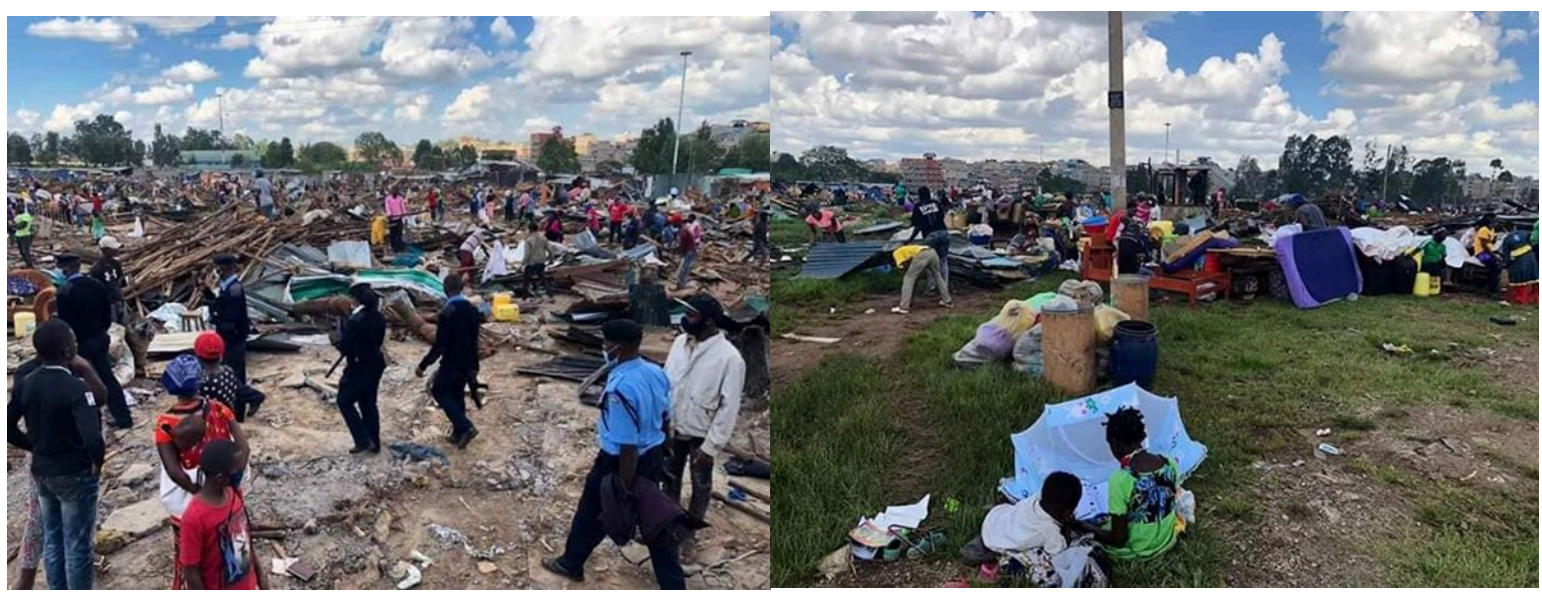

Photos: Posted by BHSEP on Facebook showing the aftermath of the demolitions in Korogocho.

\section{Criminalisation of sex workers, repressive policing and violence}

Lancet HIV (2020) reflecting on impacts of COVID-19 on key populations referred to UNAIDS reporting of 'crackdowns against sex workers, including home raids, compulsory COVID-19 testing, arrests, and threatened deportation of migrant sex workers'.

From our research in Narobi and Kenyan media reports it would seem sex workers in Kenya faced some of the more brutal police action being dealt by police globally to enforce Covid-19 regulations such as the curfew, stay at home, movement across regional boundaries. This was also the case with sex workers in other African nations experiencing repressive policing.

Also in Kenya sex workers experienced brutal policing and structural violence via the economic penalties enforced by the police, be that fines or bribes. Sex workers described how they had no choice but to work to survive but this meant the risk of encountering the police when trying to make contact with customers or after seeing customers and having to 'negotiate' their way back home. Negotiate with police, paying bribes to avoid action for curfew breaches or if crossing boundaries if they are travelling between certain areas of the city. KESWA's advocacy and challenge to policing tactics has highlighted the repressive and often violent policing of sex work during the Covid-19 crisis;

'So far, more than 50 sex workers have been forcefully quarantined, and women have been arrested for not adhering to the social distancing rules and obligatory mask-wearing. "How do you expect women to adhere to these measures when they cannot feed themselves and their families and many of them don't even have homes?" Ms Njoroge asked. Phelister Abdalla, a sex worker living with HIV and KESWA's National Coordinator, said that the police are taking advantage of the COVID-19 situation. She said that police raided guest houses more regularly and targeted the community, shaming and beating them, leaving them defenceless. ${ }^{22}$ 
In some African countries large numbers of arrest appear to have been made in the enforcement of Covid-19 regulations against sex workers, with punitive penalties. In Cameroon in late March there was media coverage of 50 sex workers arrested who were visiting customers isolating in hotels in the capital Yaounde this illustrates aggressive and stigmatising language being used by some public offficials. ${ }^{23}$

Tsila said the "smuggling of prostitutes" into hotel rooms is a "legendary act of indiscipline", adding that he has beefed up security around hotels in the capital hosting people suspected to be infected. Commercial sex workers who would be seen on the streets of the capital, Yaounde, would also be arrested and be charged with spreading the deadly virus, he said. Those arrested may face prison terms of up to three years and a fine.

In Mozambique at the end of May journalists reported the on the arrest and deportation of 53 migrant sex workers;

Police in Mozambique have deported 43 sex workers who were arrested for violating coronavirus safety protocols imposed on April 1. The Director of the police provincial command, Fernando Ribeiro, said the 43 sex workers included Zambians and Zimbabweans...Apart from the sex workers, traders and individuals were found at drinking spots and along public roads. ${ }^{24}$

In Ondo state, western Nigeria 18 sex workers and five of their clients were arrested at a brothel for 'flouting the state government's lockdown order put in place to prevent the spread of Coronavirus' a health official was reported as stating that the sex workers had been quarantined and 'their blood samples collected for tests in order to determine their health status' 25 .

Such actions including quarantine and none voluntary testing is a great concern for sex workers who have historically had their rights ignored and been scapegoated in public health crisis and raises concerns that Covid-19 regulations will be disproportionately used against sex workers and act as a cover for sex worker criminalisation and rights abuses.

\section{Reduced access to HIV services and broader health care}

A huge issue in the BHSEP sex worker interview data collected in our wider study was that of reduced access to health services for sex workers with health facilities seeing fewer people due to Covid measures, closing or restrictions of movement making it difficult for sex workers to travel to clinics and other services.

One article that appeared in the Kenyan media articles which cut to the heart of the issue of Covid19 leading to reduced access to health services including vital treatment for sex workers living with HIV was an article published on 21st May on Tuko digital news platform this focused on the closure of the Kenya Medical Research Institute (KEMRI) and it's impact on the LGBT community and sex workers. This was also only one of two of the African articles which made reference to male sex work. The report describes how this was one of the main services which sex workers and the LGBTQ community accessed for safer sex supplies and also for PrEP, HIV testing and treatment, a place which had knowledge about these communities, their health needs and did not stigmatise them, something faced in other public health facilities.

Another male sex worker, Shakira, said he had been receiving Pre-exposure prophylaxis (or PrEP) from the centre for the past 11 years and its closure meant death for him. He says that for the past two months, he has not been able to access the crucial drug adding that he is endangering his life. "I have no option but to keep on having sex with other men since I need to survive. However, the 
abrupt cut of PrEP has put me in danger and risking my clients lives," he said. He argued that business had to go on as usual since he could not visit another facility to get the essential drugs due to stigmatization. "I can't let go of my KSh 10, 000 profit business since I am the breadwinner of my family of five". This article also highlighted concerns, expressed by some NGO's and international health and humanitarian bodies that the government focus on Covid-19 was leading to a sidelining of other diseases such as HIV:

The over 500 LGBTQ raised concerns saying that the government's focus was now on the COVID-19 pandemic while patients suffering from other diseases like HIV had been neglected. It is so sad knowing that the centre had been closed because of COVID-19, putting in mind that HIV cases are going up every day and people are still having sex," he added. Chai further added that the centre is of great help not only to Mtwapa people but other people coming from Likoni area in Mombasa County, Kaloleni and Chonyi. The clergy argued that COVID-19 and HIV had no difference since no cure had been identified for both viruses.

The report described how the director of KEMRI reported they had received a government circular sent to all such facilities directing them to 'scale down their activities and focus on COVID-19 testing' and that non-essential services had to move to over facilities in measures to stop the spread of corona virus.

An editorial appeared in the medical journal the Lancet HIV (2020) on 21st May 2020 reporting that COVID-19 restriction access to HIV testing and treatment services was a concern for people with HIV and those who provide care, with the combination of interruptions to supply chains leading to antiretroviral stock outs and the closure of sexual health clinics and counselling services ' already affecting the HIV response in some countries'. More positively they documented how government and NGO services were adapting and innovating with strategies such as multi month dispensing of antiretroviral medicine, online clinics and support networks, and postal testing for sexually transmitted infections. But they raised caution about 'worrying reports about countries and regions abusing the rights of key populations affected by HIV/AIDS under the pretext of COVID-19 regulations'.

On 15th May a document was published jointly by UNAIDS, USAIDS, PEPFAR and GPC entitled ' Strategic Considerations for Mitigating the Impact of COVID-19 on Key- Population-Focused HIV Programs' (UNAIDS 2020) this document recognised that a health priority during the Covid-19 pandemic is 'continuity of treatment and support for viral suppression among people living with HIV (PLHIV), continuing to identify undiagnosed individuals and ensure their prompt enrolment on treatment, and helping those who are at risk of HIV acquisition remain HIV negative'. The aim of the document is to provide a resource containing strategies which reduce the impact of COVID-19 on key populations (including sex workers) whilst maintaining safe access to HIV testing, prevention, care, and treatment services. The document describes how for key groups stigma and discrimination means they are more likely to be targeted by law enforcement under public health and order laws, for example, for breaching restrictions or exposing others to COVID-19. Also they may be vulnerable to the virus if they cannot shelter in place or due to discriminatory targeting by police. UNAIS was already receiving reports of key population including sex workers and (LGBTI) communities being targeted.

UNAIDS (2020) advised HIV programs, especially those that cater to KPs, to put measures in place to help mitigate the impact of the COVID-19 pandemic on access to HIV prevention, care, and treatment services while simultaneously promoting the safety of staff and beneficiaries. They 
advised all measurers 'must be grounded in a human-rights-based approach, and KP communities must be engaged and empowered to participate in all aspects of the response' (pg 3).

An important journal article and very relevant reference point for our study was published in the Journal of International Public Health at the end of May (Kimani et al., 2020). This looked at how the health and socio economic status of sex workers in Nairobi had been effected by Covid-19 crisis. The article was specifically looking at how these effects were 'intersecting' with HIV. The authors included representatives from sex worker projects on the ground in Nairobi and the article described how sex worker programs in Nairobi such as BHSEP who use a peer model, were maintaining sexual health services but with s number of changes with for example moving to appointment systems, limits on numbers of people accessing, instigating physical distancing, operating counselling services by phone, staff using PPE and hand sanitisers. Kimani et al., reported that 'food insecurity' was now the main source of distress for sex workers and hence a grant had been secured and food distributed.

\section{Lorry drivers and sex workers: a moral panic?}

Perhaps one group who in African media have been constructed as vectors of transmission for corona virus, at least on a level with sex workers, are truck drivers. With main East African goods transport routes starting from the Coastal ports of Mombassa, Kenya and Dar al Salaam, Tanzania reaching into Uganda, Rawanda and Zambia, the identification of lorry drivers as a key vector of transmissions of corona virus across and within national borders due to their mobility and their social and sexual association with sex workers was one of the main themes emergent from African media analysis. This was a prominent issue related to Kenya, particularly in relation to its neighbour Uganda, with Kenyan drivers being identified as problematic. As discussed earlier this was a key theme in the African media literature due to reportage of this by East African media outlets.

The first reporting in our searches was in the Uganda press on $21^{\text {st }}$ April headlined 'Drama as 30 sex workers and their clients arrested and quarantined' ${ }^{26}$. This described police actions at lodges in Emali town, Makueni County, where they 'arrested commercial sex workers and their clients for flouting the social distance rules meant to stop the spread of coronavirus'. All were taken to a girls school for 14 days quarantine. The article stated;

Majority of the sex workers depend on truck drivers using the busy highway Nairobi-Mombasa highway and revellers. The 'stay at home order' has therefore affected their earning as clients are depleted due to restricted movements'.

This was followed by more reporting in the Ugandan press ${ }^{27}$ on $23^{\text {rd }}$ April with health officials identifying lorry drivers and sex workers as risky transmitters of Covid-19.

Maracha District Health Officer (DHO) has cautioned that despite Uganda's 'excellent performance in containing the spread of COVID-19, long-distance drivers and commercial sex workers are likely to endanger the Pearl of Africa'.

The Ugandan government closed lodges as part of its Covid response. On May $1^{\text {st }}$ one Kenyan truck driver faced particular scapegoating in an article. This driver, who had tested positive when he had crossed to Rwanda, was identified as being 'dishonest about his associations ${ }^{28}$, military intelligence were then involved in his contact tracing, the article named him. The military took his phone to trace his movements. He said he stayed in his truck but he was not believed as he had parked near a bar 'infamous for lots of sex workers'. The district Chairperson said they would 'hunt for whoever 
contacted the driver to make sure they were quarantined'. This was reported in Kenyan media also. $^{29}$

Whilst the lorry driver relationship with sex workers may well be specific to certain continental thoroughfares in Africa, the theme remains constant that where sex workers find their business and earn a living have been put under severe threat during the Covid restrictions. With no recourse to public protection these changes in the customer base leave dire consequences for the women.

\section{Peer Advice: African Sex Worker Alliance}

UNAIDS called on countries to act to protect health and rights of sex workers based on human rights principles listing a range of actions, one of these was that sex workers themselves should be meaningfully involved in interventions and public health planning. Examples of actions were;

- Access to national social protection schemes for sex workers, including income support schemes.

- In relation to migrant sex workers, an immediate firewall between health services and immigration authorities in order to ensure that migrant workers can access health services. Extensions on visas due to expire as travel restrictions tighten. Immigration detention systems to support detainees in safe accommodation.

- Emergency financial support for sex workers facing destitution, particularly migrants who are unable to access residency-based financial support.

- A stop to evictions and provision of emergency housing for homeless sex workers.

- Stopping raids on sex workers' homes and sex work premises and ensuring that all measures to protect public health are proportionate.

- Ending arrests and prosecutions for sex work-related activity

- An end to the use of criminal law to enforce COVID-19-related restrictions, including forced COVID-19 testing and related prosecutions.

The African Sex Worker Alliance (ASWA, based in Kenya) works for the health and human rights of all sex workers across Africa. On the $8^{\text {th }}$ March ASWA posted a blog '\#Covid 19: Useful protection measures for sex workers', this remains their featured post prominent on their website homepage ${ }^{30}$. This featured detail about key measures to protect against Covid-19 (See figure 1).

Figure 1: African Sex Worker Alliance Advice to Sex Workers on COVID. 


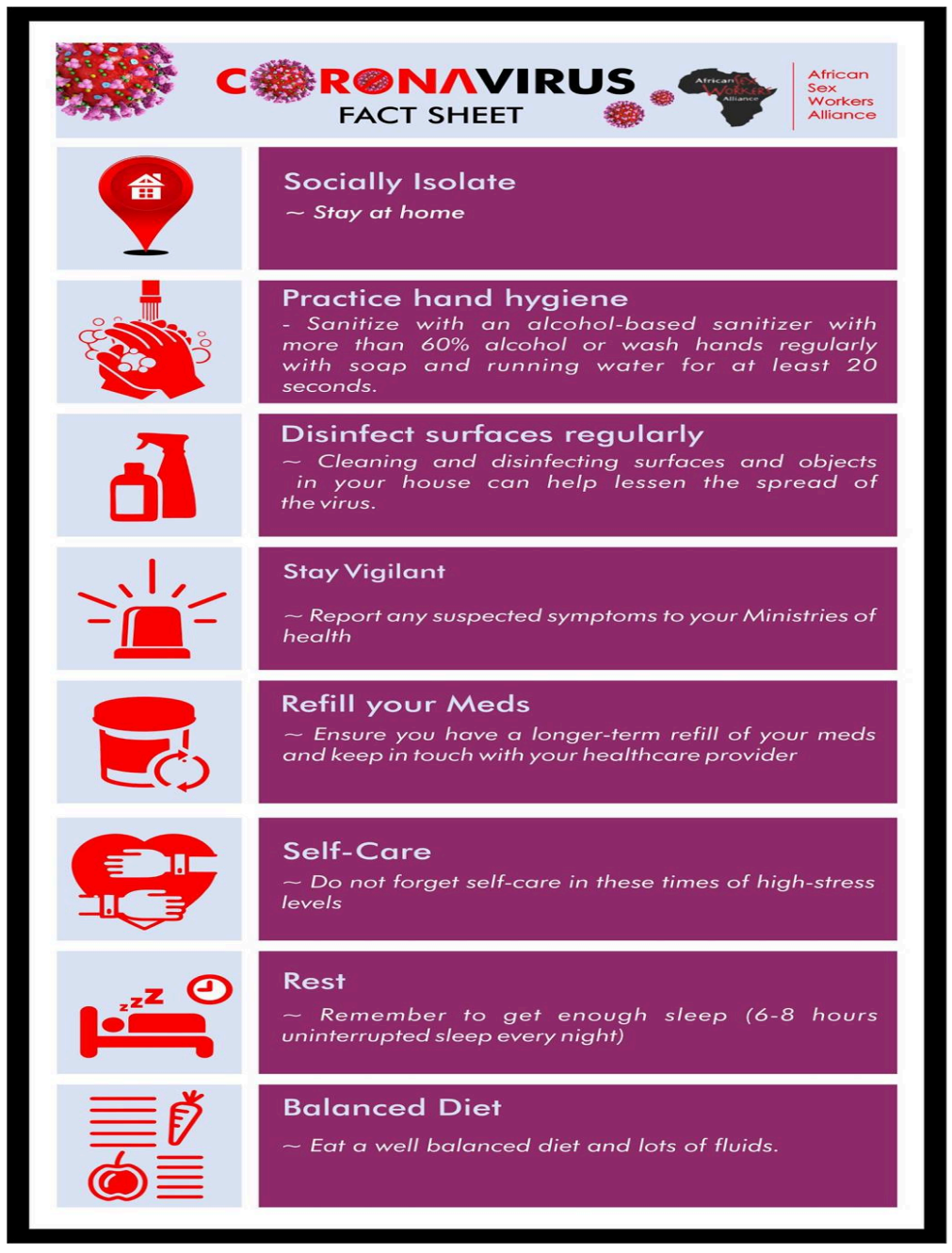

ASWA produced an infographic to communicate key messages for sex workers about how to reduce the risk of catching the virus (Figure 2), thinking directly about those who are continuing to have close physical contact with clients during the social distancing measures. 


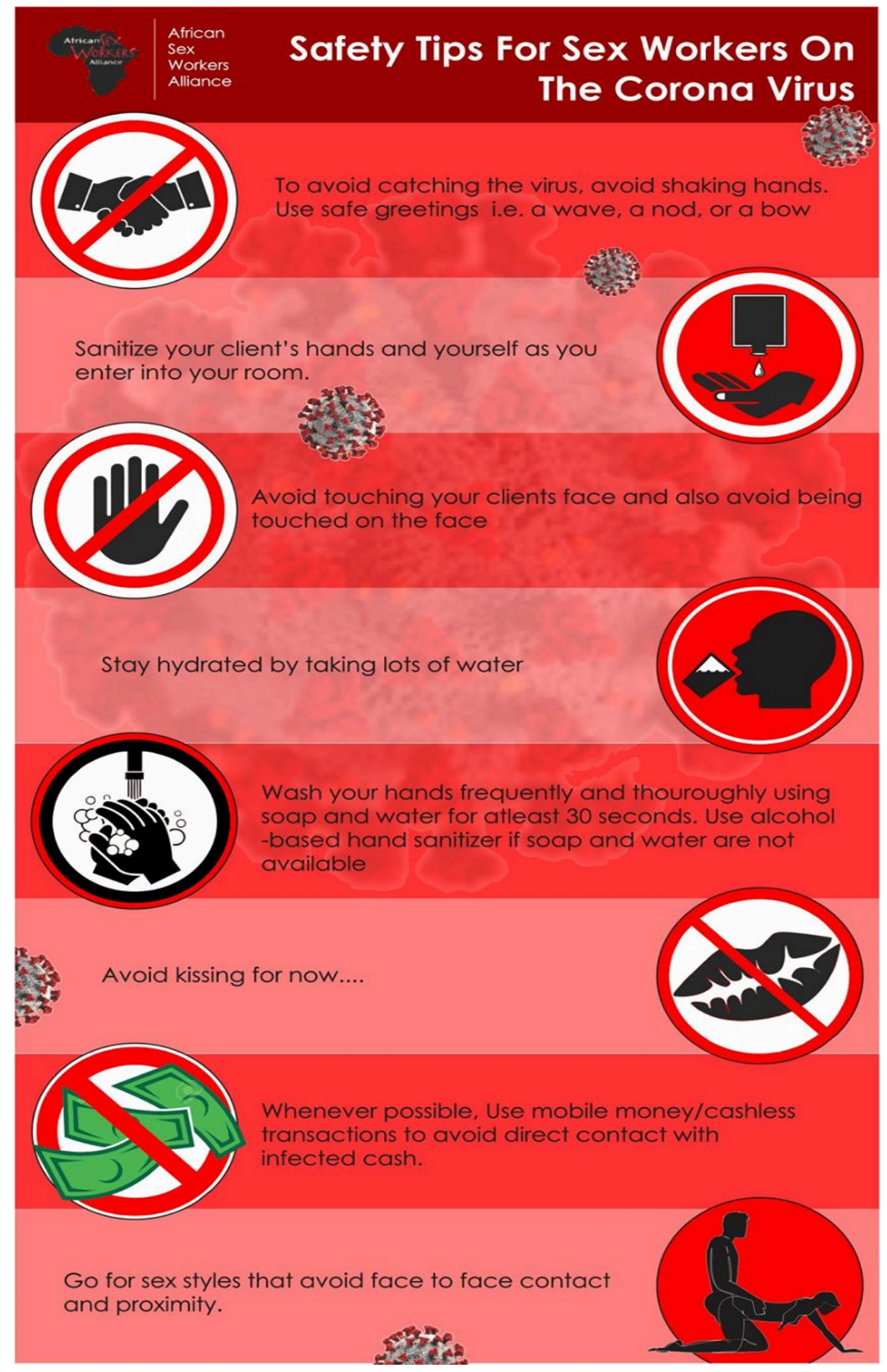

Figure 2: ASWA Safety Tips for Sex workers During COVID. 
These national messages for sex workers across Africa have been reinforced by localised projects. Bar Hostess Empowerment and Support Program have been using social media to regularly post information about staying safe as well as their enhanced services and emergency provisions. BHESP published a blog on $12^{\text {th }}$ May entitled 'Covid 19: Sex workers livelihood hangs in balance amidst uncertainty'. ${ }^{31}$ This updated on the conditions sex workers were facing. Again BHESP highlighted that with bar closures and survival pressures meaning sex workers needed to work to survive, they were having to work in more risky settings such as from their homes or that of their clients. With low or no income, preventative measures such a face masks are unaffordable. This blog also reported the adverse consequences of the demolitions in Korogocho, with some facing hunger, homelessness and no place to work to earn money to address these. The following is a quote from a sex work who BHESP spoke with who was evicted:

'I received no prior notice of eviction. All I saw were bulldozers this morning and the police evicting us. How will I manage to bring food on the table now that my hotspot has been demolished?'

Concern was also expressed that there would be consequences for sex workers health as condom distribution by BHSEP to sex workers was more difficult with known workplaces and residences gone and the organising finding HIV positive sex workers were finding it harder to obtain Anti Retro Viral treatment refills from their clinics. Throughout the crisis BHSEP (through its Facebook, Twitter and You Tube accounts), has provided practical information about coronavirus for sex workers (including information about HIV and HIV treatment services during the corona virus pandemic) and services available. Practical tips around hand washing and wearing a mask correctly were promoted through their social media posts (see Figure 3 ).

BHESP @bhesp . 19 Apr

Learn how to use and dispose a mask.\#COVID19 \#KomeshaCorona \#StaySafe \#Covid_19.
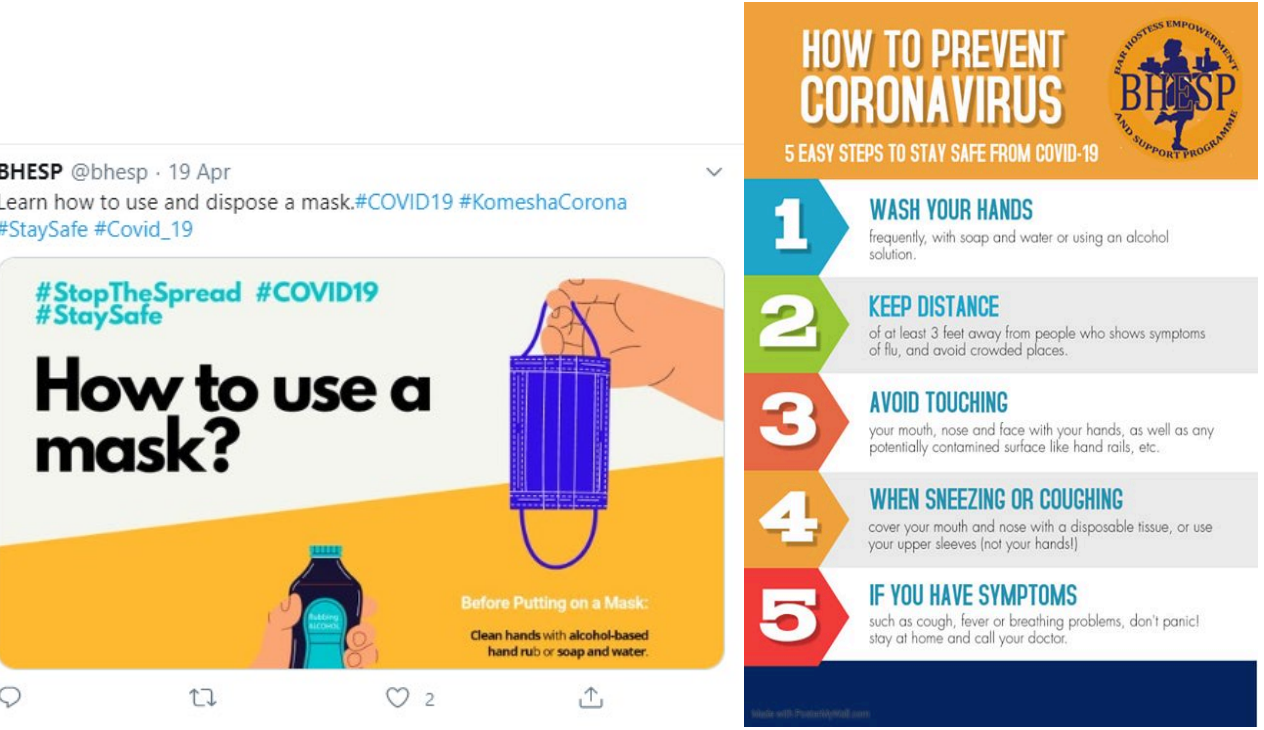

Figure 3. Information from BHESP to sex workers shared via social media 


\section{Concluding thoughts}

Significant cohorts of sex workers in many countries are drawn from marginalised populations for example migrants (including refugees), homeless populations and those living within informal settlements or slum areas, people living with HIV and the LGBTQ community. Such marginalised sex workers have been particularly affected by the government restrictions and lack of safety nets for those working in informal economies and living in informal settlements. In this paper we have documented the immediate impacts and consequences on working practices, housing, access to health care, problems associated with restricted mobility and the destitution of many sex workers, particularly in Nairobi. The future looks very desperate for sex work communities across Africa, as the global recession will heighten inequalities and particularly make women the carriers of deep rooted economic problems (Care International 2020).

We hope that a raft of analytical material produced through research, NGO's, campaign groups, and human rights campaigns will highlight the specific and multi-dimensional issues that sex workers face. The findings here show that there are a significant number of inter-related issues for sex workers across the globe that require immediate and critical interventions from governments. Policy responses should be based on these common themes, and the specific issues facing women in the African context. By drawing attention to the many issues which are specific to sex workers (such as their working places being closed down, income severance, the effects of criminalisation, gender based violence, sexual and reproductive health inequalities etc.) interventions can be tailored to the immediate and short term needs of sex workers who are left destitute in so many ways. The media have often done a major disservice to sex workers in representing their experiences, but with the case of COVID-19, the media have been a useful platform to express the unique experiences of sex workers. These findings should be fed into policy agendas, service provisions, government interventions and broader campaigns for health equality and social justice for women at this critical time.

\section{Reference list}

Birdthistle, I., Tanton, C., Tomita, A., de Graaf, K., Schaffnit, S. B., Tanser, F., \& Slaymaker, E. (2019). Recent levels and trends in HIV incidence rates among adolescent girls and young women in ten high-prevalence African countries: a systematic review and meta-analysis. The Lancet Global Health, 7(11), e1521-e1540.

Care International (2020) Covid 19 could condemn women into decades of poverty. https://insights.careinternational.org.uk/publications/covid-19-could-condemn-women-to-decadesof-poverty-implications-of-the-covid-19-pandemic-on-women-s-and-girls-economic-justice-andrights

Danish Refuge Council (2020) The Ripple Effect of Covid 19 on economic activities, livelihoods and food security in East Africa and the Great Lakes https://reliefweb.int/report/somalia/ripple-effectcovid-19-economic-activities-livelihoods-and-food-security-east-africa

Deering, K. N., Amin, A., Shoveller, J., Nesbitt, A., Garcia-Moreno, C., Duff, P., ... \& Shannon, K. (2014). A systematic review of the correlates of violence against sex workers. American journal of public health, 104(5), e42-e54.

Howard S (2020) Covid-19: Health needs of sex workers are being sidelined, warn agencies, British Medical Journal, 369:m1867 doi: 10.1136/bmj.m1867 (Published 7 May 2020) 
ICRSE and SWAN (2020) Covid 19 impact on sex worker access to health services for sex workers in Europe and Central Asia, ICRSE.

http://www.sexworkeurope.org/sites/default/files/userfiles/files/Covid19 SWAN\%26ICRSE Final In teractive $\% 20 \% 281 \% 29 . p d f$

Kimani J, Adhiambo J, Kasiba R, Mwangi P, Were V, Mathenge J, Macharia P, Cholette F, Moore S, Shaw S, Becker M, Musyoki H, Parinita B, Moses S, Fowke KR, McKinnon L R and Lorway, R (2020) The effects of COVID-19 on the health and socioeconomic security of sex workers in Nairobi, Kenya: Emerging intersections with HIV, Global Public Health, 1744-1706,

DOI:10.1080/17441692.2020.1770831.

Lancet HIV (2020) 'Lockdown fears for key populations' https://doi.org/10.1016/ S2352-

3018(20)30143-0 https://www.thelancet.com/action/showPdf?pii=S2352-3018\%2820\%2930143-0

PIC and Sexwerkexpertise (2020) Survey on sex workers' access to corona support in the Netherlands: paying taxes, PIC and Sexwerkexpertise.

Platt L, Elmes J, Stevenson L, Holt V, Rolles S, Stuart R (2020) Sex workers must not be forgotten in the COVID-19 response, The Lancet, https://doi.org/10.1016/ S0140-6736(20)31033-3.

Wenham C, Smith J, Morgan R (2020) COVID-19: the gendered impacts of the outbreak, The Lancet, https://doi.org/10.1016/S0140-6736(20)30526-2.

UNAIDS, USAIDS, PEPFAR and GPC (2020) 'Strategic Considerations for Mitigating the Impact of COVID-19 on Key- Population-Focused HIV Programs', UNAIDS.

UNAIDS (2020) COVID-19 responses must uphold and protect the human rights of sex workers, UNAIDS, Geneva, Switzerland.

${ }^{1}$ https://www.unaids.org/en/resources/presscentre/pressreleaseandstatementarchive/2020/may/20200511 PR HIV modelling?fbclid=IwAR1QutsIzVALY3q06TjAkCpj5iTwr-Obj|ruSE5d-secl1ewylw3YOLXP8A

${ }^{2}$ This research is funded by QR Global Challenges Research Fund / Research England

${ }^{3}$ https://www.reuters.com/article/us-health-coronavirus-women-sexworkers/hunger-or-murder-lockdownpoverty-exposes-african-sex-workers-to-more-violence-idUSKBN23BOCS

${ }^{4}$ https://www.nswp.org/news/sex-workers-must-not-be-left-behind-the-response-Covid-19

${ }^{5}$ https://www.nswp.org/news/Covid-19-impact-senegal

${ }^{6}$ We would also like to note, that whilst in the African context this was not a prominent feature, however during the crisis of Covid there was a trend of more workers moving to digital online sex work platforms across the global north.

${ }^{7}$ https://www.unaids.org/en/resources/presscentre/featurestories/2020/may/20200520 kenya

${ }^{8}$ https://www.namibian.com.na/91007/read/Oshikango-red-light-district-dims

${ }^{9}$ https://www.news24.com/SouthAfrica/News/sex-workers-Covid-misery-20200511-2

${ }^{10}$ https://www.sde.co.ke/article/2001367162/no-clients-nairobi-hookers-hit-hard-by-Covid-19-curfew

${ }^{11}$ https://www.sde.co.ke/article/2001367162/no-clients-nairobi-hookers-hit-hard-by-covid-19-curfew

${ }^{12}$ https://www.voanews.com/africa/struggling-sex-workers-botswana-get-food-aid

${ }^{13}$ https://www.ghanaweb.com/GhanaHomePage/NewsArchive/Coronavirus-destroying-our-business-sales-atall-time-low-Prostitutes-908971

${ }^{14}$ http://saharareporters.com/2020/05/04/Covid-19-ondo-sex-workers-devise-new-tactics-keep\%E2\%80\%98business\%E2\%80\%99-alive 
${ }^{15}$ https://www.sde.co.ke/article/2001367162/no-clients-nairobi-hookers-hit-hard-by-Covid-19-curfew

${ }^{16}$ https://www.independent.co.uk/news/long reads/coronavirus-east-africa-kenya-tanzania-truckers-testinga9532686.html

${ }^{17}$ https://www.news24.com/SouthAfrica/News/sex-workers-Covid-misery-20200511-2

${ }^{18}$ https://www.groundup.org.za/article/much-l-am-afraid-Covid-19-I-need-money-says-sex-worker/

${ }^{19} \mathrm{http}: / /$ saharareporters.com/2020/05/04/Covid-19-ondo-sex-workers-devise-new-tactics-keep-

\%E2\%80\%98business\%E2\%80\%99-alive

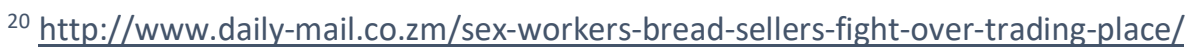

${ }^{21}$ https://www.sde.co.ke/article/2001367162/no-clients-nairobi-hookers-hit-hard-by-Covid-19-curfew

${ }^{22}$ https://www.unaids.org/en/resources/presscentre/featurestories/2020/may/20200520 kenya

${ }^{23}$ https://face2faceafrica.com/article/cameroon-police-arrest-sex-workers-offering-services-at-coronavirusisolation-centers

${ }^{24}$ https://www.theghanareport.com/43-sex-workers-deported-from-mozambique/

${ }^{25}$ https://sundiatapost.com/Covid19-drama-as-sex-workers-and-their-clients-are-arrested-for-floutinglockdown-order-in-ondo/

${ }^{26}$ https://www.standardmedia.co.ke/article/2001368721/30-sex-workers-and-their-clients-arrestedquarantined

${ }^{27}$ https://redpepper.co.ug/2020/04/sex-workers-resort-to-truck-drivers-undermining-Covid-19-fight-inmaracha/

${ }^{28}$ https://chimpreports.com/covi19-cmi-probes-lying-kenyan-truck-driver/

${ }^{29}$ https://www.kenyans.co.ke/news/52726-police-investigate-kenyan-Covid-19-patient-rwanda

${ }^{30} \mathrm{https}$ ://aswaalliance.org/vous-trouverez-ci-joint-une-brochure-produite-par-laswa-pour-informer-eteduquer-sur-Covid-19/

${ }^{31}$ https://bhesp.org/index.php/component/k2/item/58-covid19-sex-workers-livelihood-hangs-in-balanceamidst-uncertainty 